Document title

Study title

Study drug

Studied indication

Development phase

Protocol code

Study initiation date

Study completion date

Main coordinator

Company / Sponsor

Responsible medical officer $G C P$

Date of the report

\section{Clinical Study Report Synopsis}

The efficacy and safety of two doses of strontium ranelate (1g and $2 \mathrm{~g}$ per day) versus placebo administered orally for 3 years $(2$ years initially planned then extended to 3 years by Amendment No. 11) in the treatment of knee osteoarthritis.

A prospective multicentre, international, double-blind, placebo controlled study.

S 12911

Osteoarthritis

Phase III

CL3-12911-018

28 April 2006

17 February 2011

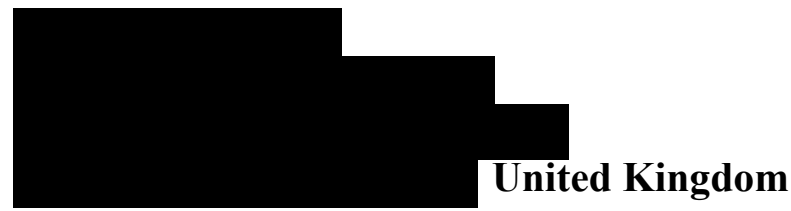

Institut de Recherches Internationales Servier (I.R.I.S.)

50, rue Carnot

92284 Suresnes Cedex - France

Servier Canada Inc.

235, Armand Frappier Blvd

H7V 4A7 Laval (QC)- Canada

Laboratorios Servier

Avenida de los Madronos

3328043 Madrid - Spain

Servier Research and Development

Gallions, Whexham Springs - Framewood Road Wexham

Slough SL3 6RJ - United Kingdom

This study was performed in accordance with the principles of Good Clinical Practice including the archiving of essential documents.

Final version of 20 March 2012 


\section{SYNOPSIS}

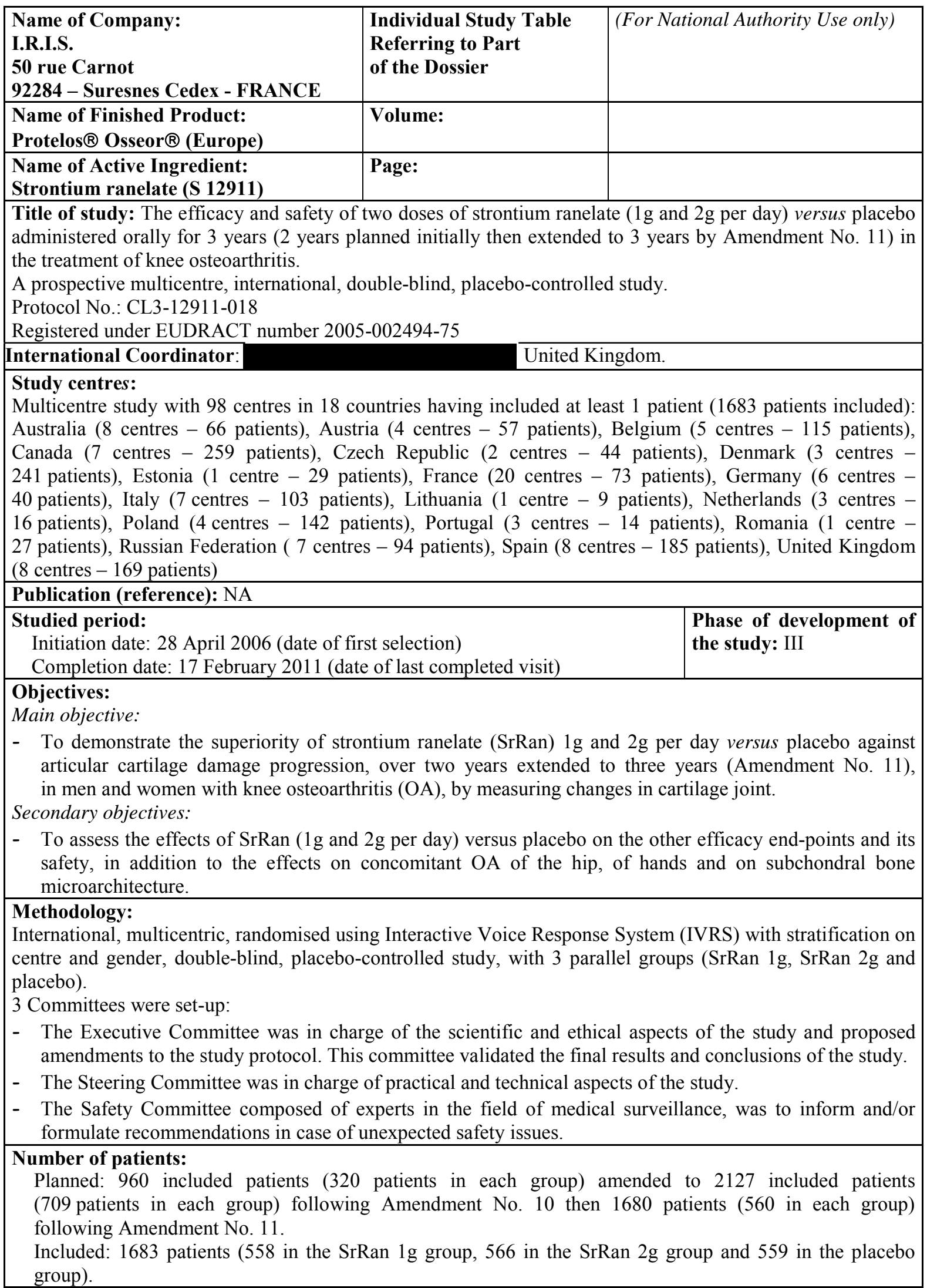




\begin{tabular}{|c|c|c|}
\hline & & (For National Authority Use \\
\hline $\begin{array}{l}\text { Name of Finished Product: } \\
\text { Protelos } ® \text { Osseor } ® \text { (Europe) } \\
\end{array}$ & Volu & \\
\hline & Page: & \\
\hline \multicolumn{3}{|c|}{$\begin{array}{l}\text { Diagnosis and main criteria for inclusion: } \\
\text { Caucasian, ambulatory, men and women aged } \geq 50 \text { years, with a primary knee OA of the medial femoro-tibial } \\
\text { compartment diagnosed according to the clinical and radiological criteria of the American College of } \\
\text { Rheumatology, a presence of Kellgren and Lawrence grading stages II or III on knee X-rays and a Joint Space } \\
\text { Width (JSW) of at least } 3 \mathrm{~mm} \text {, modified by Amendment No. } 9 \text { to JSW between } 2.5 \text { and } 5 \mathrm{~mm} \\
\text { (inclusive limits). A target knee was defined taking into account the Kellgren and Lawrence score, } \\
\text { the anatomic compartment, and the VAS value at inclusion, and was then to be followed during the study. }\end{array}$} \\
\hline \multicolumn{3}{|c|}{$\begin{array}{l}\text { Study drug: } \\
\text { Strontium Ranelate given orally as sachet of granules of } 1 \mathrm{~g} \text { or } 2 \mathrm{~g} \text { taken as a suspension once daily at bedtime. }\end{array}$} \\
\hline \multicolumn{3}{|c|}{$\begin{array}{l}\text { Reference product: } \\
\text { Matching placebo sachet given orally as a suspension once daily at bedtime. }\end{array}$} \\
\hline \multicolumn{3}{|c|}{$\begin{array}{l}\text { Duration of treatment: } \\
\text { From selection visit (W-2) to M0: period without study treatment } \\
\text { Active treatment period (M0-M36): } 24 \text { months extended to } 36 \text { months (Amendment No. 11) with } \\
\text { two additional visits M30 and M36 and one additional phone call at M27 }\end{array}$} \\
\hline \multicolumn{3}{|c|}{$\begin{array}{l}\text { Criteria for evaluation: } \\
\text { Efficacy measurements }\end{array}$} \\
\hline \multicolumn{3}{|c|}{$\begin{array}{l}\text { Primary efficacy endpoint: } \\
\text { Radiographic progression of knee osteoarthritis by assessment of the JSW at selection, M12, M24 and M } 36 \\
\text { visits (standardised assessment and centralised reading by PMO, Prevention des Maladies Osseuses, Lyon, } \\
\text { France). The measurement of the mean change versus placebo in the minimal JSW of the medial femoro-tibial } \\
\text { compartment was determined by X-ray. } \\
\text { A second independent central reading of knee X-ray using the same device and reading method was set up in } \\
\text { LIEGE (Liege - Belgium). }\end{array}$} \\
\hline \multicolumn{3}{|c|}{$\begin{array}{l}\text { - Algo-functional assessment of the target knee by the WOMAC index score (Western Ontario and } \\
\text { - VcMaster Universities Osteoarthritis Index) every } 6 \text { months from M0 to M36. } \\
\text { Visual Analogic Score (VAS) for the target knee pain scale assessment at selection, M0, and every } \\
6 \text { months up to M36 with a recall period of } 48 \text { hours. } \\
\text { - Target knee physical assessment at each visit. } \\
\text { - Time to surgery for the target knee joint replacement amended to time to indication to surgery for } \\
\text { target knee joint replacement (Amendment No. 10). }\end{array}$} \\
\hline \multicolumn{3}{|c|}{$\begin{array}{l}\text { - E-diary filled in by the patient: knee pain flare frequency and intensity, and pain medication consumption } \\
\text { through a once weekly phone call. } \\
\text { - SF36 Quality of Life Questionnaire self-administered questionnaire filled in at M0, and then every } \\
6 \text { months up to M36. } \\
\text { - Knee Magnetic Resonance Imaging (MRI), assessing the cartilage volume and other parameters } \\
\text { (performed in a subset of patients) at M0, M12, M24 and M36 visits. } \\
\text { - } \text { Biochemical bone markers: serum Bone ALkaline Phosphatase (bALP) and C-terminal Telopeptides of } \\
\text { type I collagen (CTX I) and cartilage markers: serum C Propeptide of type II procollagen (CPII) and } \\
\text { urinary C-terminal Telopeptides of type II collagen (CTX II) and one marker of synovial metabolism } \\
\text { Hyaluronic Acid (HA), at M0, M3, M6, M12, M24, M30, and M36. }\end{array}$} \\
\hline
\end{tabular}




\begin{tabular}{|l|l|l|}
\hline $\begin{array}{l}\text { Name of Company: } \\
\text { I.R.I.S. } \\
\text { 50 rue Carnot } \\
\text { 92284 - Suresnes Cedex - FRANCE }\end{array}$ & $\begin{array}{l}\text { Individual Study Table } \\
\text { Referring to Part } \\
\text { of the Dossier }\end{array}$ & (For National Authority Use only) \\
\hline $\begin{array}{l}\text { Name of Finished Product: } \\
\text { Protelos } ® \text { Osseor } ® \text { (Europe) }\end{array}$ & Volume: & \\
\hline $\begin{array}{l}\text { Name of Active Ingredient: } \\
\text { Strontium ranelate (S 12911) }\end{array}$ & Page: & \\
\hline
\end{tabular}

Criteria for evaluation (Cont'd):

- Hand radiological and clinical assessment:

- Radiologic assessment of hand osteoarthritis at M0 and M36.

- Clinical assessment of hand osteoarthritis.

- Algo-functional assessment by AUStralian CANadian hand osteoarthritis Index (AUSCAN) and functional assessment by FIHOA index, in countries where these index were linguistically validated. As AUSCAN (self-administered) and FIHOA (doctor-administered) questionnaires relate similarly to the functional aspects of the hand OA, but are administered in a different way, both hand osteoarthritis indices were employed at M0, M12, M24 and M36 visits.

- Clinical assessement by the investigator of pain in finger joints at M0, M12, M24, and M36 visits and of finger nodes at M0 and M36 visits only.

- Clinical assessment of both hips: pain assessed by the VAS score and physical examination at M0, M12, M24 and M36 visits.

- Exploratory assessments:

- In addition to the central reading by PMO, the knee X-ray was evaluated by Synarc (San Fransisco, USA) using an exploratory method.

- Radiological progression defined via an algorithm.

- Subchondral bone architecture assessment at the knee level by non-invasive high resolution tomodensitometric method (CT-scan in selected centres) at M0 and M36.

- Pharmacoeconomic assessment (need for: physiotherapy, nursing care sessions, paramedical sessions, additional medical imaging procedures or physician visits, hospitalisation for knee inflammation, total knee replacement, knee arthroscopy, rehabilitation unit admission and water cures, drugs consumption) at M3 visit (Amendment No. 8), M6, M12, M18, M24, M30 and M36.

Safety measurements:

- Adverse events reported at each visit.

- Vital signs (weight, height, systolic and diastolic blood pressure, heart rate) at each visit.

- Laboratory safety parameters: biochemistry parameters [total alkaline phosphatase, ASAT, ALAT, GGT, blood and urinary creatinine, phosphorus, blood and urinary calcium, sodium, potassium, chloride, albumin, C-reactive protein, CPK (and isoenzymes if CPK above the upper limit of the reference range)] and haematology parameters (blood cell count, haemoglobin, haematocrit, MCV) at selection, M3, M6, M12, M18, M24, M30 and M36 except for sodium, potassium, chloride assessed only at selection, M12, M24 and M36 visits.

- Haemostasis parameters (prothrombin time, activated partial thromboplastine time, prothrombin activation peptide (F1 + F2 fragments), fibrinogen, antithrombin III, protein C, protein S, factor VIII, homocystein (and folic acid and vitamin B12 if homocystein above the upper limit of the reference range), antiphospholipid antibodies assessed at M0, M6, M12, M24 and M36.

Pharmacokinetic measurements

To assess the pharmacokinetics (PK) of strontium in patients with knee osteoarthrisis, serum samples were collected in all patients in the morning of M0, M3, M6 and every 6 months up to M36. Additionally, at M6 and M18, in a subgroup, the patients were asked to take their daily treatment in the morning during the visit, after the first blood collection. In these patients, an additional blood sample was collected between $1 \mathrm{~h} 30$ and $4 \mathrm{~h}$ after the morning study treatment intake. At M30, in the same subgroup, an additional blood sample was collected between $1 \mathrm{~h} 30$ and $4 \mathrm{~h}$ after the first sampling in the morning but without taking any medication before.

Serum concentrations of strontium were assessed by high frequency inductively coupled plasma atomic emission spectrometry (ICP-AES). 


\begin{tabular}{|c|c|c|}
\hline $\begin{array}{l}\text { Name of Company: } \\
\text { I.R.I.S. } \\
50 \text { rue Carnot } \\
92284 \text { - Suresnes Cedex - FRANCE }\end{array}$ & $\begin{array}{l}\text { Individual Study Table } \\
\text { Referring to Part } \\
\text { of the Dossier }\end{array}$ & (For National Authority Use only) \\
\hline $\begin{array}{l}\text { Name of Finished Product: } \\
\text { Protelos } ® \text { Osseor } ® \text { (Europe) }\end{array}$ & Volume: & \\
\hline $\begin{array}{l}\text { Name of Active Ingredient: } \\
\text { Strontium ranelate (S 12911) }\end{array}$ & Page: & \\
\hline \multicolumn{3}{|l|}{ Statistical methods: } \\
\hline \multicolumn{3}{|c|}{ Study outcome: descriptive statistics were provided. } \\
\hline \multicolumn{3}{|c|}{$\begin{array}{l}\text { Efficacy analyses were primarily performed in the Full Analysis Set (FAS) defined as all randomised patients } \\
\text { who took at least one dose of the study treatment and who had one assessable baseline and at least one } \\
\text { assessable post-baseline evaluation of the JSW as defined by the central reader located in Lyon (PMO). } \\
\text { The analyses were also performed in the PPS, defined as all patients of the FAS without relevant deviations } \\
\text { which could affect the evaluation of the JSW. }\end{array}$} \\
\hline \multicolumn{3}{|c|}{$\begin{array}{l}\text { Primary criterion } \\
\text { Main Analysis } \\
\text { The JSW (from PMO reading) was expressed as the change from baseline to last post-baseline value. } \\
\text { Each SrRan group was compared to the placebo group in the FAS using a general linear model } \\
\text { (with Dunnett's multiple comparison procedure, placebo being the reference group) with baseline JSW, } \\
\text { centre and gender as covariates. Estimates (E) of the difference between adjusted group means and Standard } \\
\text { Error (SE) of the estimate were provided with its } 95 \% \text { CI and the associated p-value. The main analysis was } \\
\text { also performed on the Per Protocol Set (PPS). }\end{array}$} \\
\hline \multicolumn{3}{|c|}{$\begin{array}{l}\text { Sensitivity analyses } \\
\text { The SrRan groups were compared to the placebo group on the evolution of JSW change over time using } \\
\text { different statistical models (mixed model for repeated measurements, multiple imputation, pattern mixture } \\
\text { model). A sensitivity analysis was also performed in the Randomised Set after substitution of missing values } \\
\text { by the mean level in the placebo group. } \\
\text { JSW results from LIEGE reading } \\
\text { SrRan } 1 \mathrm{~g} \text { and SrRan } 2 \mathrm{~g} \text { treatment groups were compared to placebo on the change from baseline to each visit, } \\
\text { using a general linear model with baseline, gender and centre as covariates. }\end{array}$} \\
\hline \multicolumn{3}{|l|}{$\begin{array}{l}\text { Secondary Analyses } \\
\text { The main analysis was } \\
\text { the target knee equal } t \\
\text { to the change and the } r\end{array}$} \\
\hline \multicolumn{3}{|l|}{$\begin{array}{l}\text { The SrRan } 1 \mathrm{~g} \text { and SrRan } 2 \mathrm{~g} g r \\
\text { - } \quad \text { Radiological and radio-clin } \\
\text { a Chi test. } \\
\text { - Clinical assessments }\end{array}$} \\
\hline \multicolumn{3}{|r|}{$\begin{array}{l}\text { the WOMAC scores absolute and } \\
\text { ising a mixed model for repeated } \\
\text { te change with baseline value. } \\
\text { re performed. } \\
\text { er of swelling / warmth / effusion } \\
\text { d centre as covariates. } \\
\text { ve statistics were provided. } \\
\text { od until M } 36 \text { on the number of } \\
\text { ity of pain, the mean numbers of } \\
\text { on and mean dose/week). } \\
\text { steoarthritis score were performed }\end{array}$} \\
\hline
\end{tabular}




\begin{tabular}{|c|c|c|}
\hline $\begin{array}{l}\text { Name of Company: } \\
\text { I.R.I.S. } \\
\text { 50 rue Carnot } \\
\text { 92284 - Suresnes Cedex - FRANCE }\end{array}$ & $\begin{array}{l}\text { Individual Study Table } \\
\text { Referring to Part } \\
\text { of the Dossier }\end{array}$ & (For National Authority Use only) \\
\hline $\begin{array}{l}\text { Name of Finished Product: } \\
\text { Protelos } ® \text { Osseor } ® \text { (Europe) }\end{array}$ & Volume: & \\
\hline $\begin{array}{l}\text { Name of Active Ingredient: } \\
\text { Strontium ranelate (S 12911) }\end{array}$ & Page: & \\
\hline \multicolumn{3}{|l|}{$\begin{array}{l}\text { Statistical methods (Cond't): } \\
\text { Efficacy analyses (Cont'd) } \\
\text { Secondary criteria (Cont'd) }\end{array}$} \\
\hline \multicolumn{3}{|c|}{$\begin{array}{l}\text { Knee MRI parameters: comparisons were performed on the absolute and relative change from baseline to } \\
\text { each visit, using a general linear model with baseline (only for absolute change), gender and centre as } \\
\text { covariates. }\end{array}$} \\
\hline \multicolumn{3}{|c|}{ - Biochemical cartilage and bone markers: similar analyses as for the MRI parameters were performed. } \\
\hline \multicolumn{3}{|c|}{ - Hand radiological and clinical assessment: } \\
\hline \multicolumn{3}{|c|}{$\begin{array}{l}\text { - Hand osteoarthritis X-ray evaluation: comparisons were performed on the absolute and relative change } \\
\text { from baseline to last post-baseline value, using a general linear model with baseline (only for absolute } \\
\text { change), gender and centre as covariates. } \\
\text { - Algo-functional assessment of hand: SrRan } 1 \mathrm{~g} \text { and SrRan } 2 \mathrm{~g} \text { treatment groups were compared to } \\
\text { placebo on the change (relative change) from baseline to last post-baseline value of AUSCAN score } \\
\text { and FIHOA score, using a general linear model with baseline (only for absolute change), gender and } \\
\text { centre as covariates. }\end{array}$} \\
\hline \multicolumn{3}{|c|}{$\begin{array}{l}\text { - Hip clinical assessment: descriptive statistics were provided for each treatment group for the functional } \\
\text { assessment, the VAS, and the occurrence of hip prosthesis implantation. }\end{array}$} \\
\hline \multicolumn{3}{|c|}{ - Exploratory assessments: } \\
\hline \multicolumn{3}{|c|}{$\begin{array}{l}\text { - JSW from Synarc reading: comparisons were performed on the change from baseline to each visit, } \\
\text { using a general linear model with baseline, gender and centre as covariates. }\end{array}$} \\
\hline \multicolumn{3}{|c|}{ - Radiological progression defined via an algorithm: comparisons were performed using a $\mathrm{Chi}^{2}$ test. } \\
\hline \multicolumn{3}{|c|}{$\begin{array}{l}\text { - Knee subchondral bone architecture (CT-scan): change from baseline to the last post-baseline value on } \\
\text { treatment were provided for each treatment group. }\end{array}$} \\
\hline \multicolumn{3}{|c|}{ - Pharmacoeconomic parameters: descriptive statistics were provided for each treatment group. } \\
\hline \multicolumn{3}{|c|}{ Safety analysis: } \\
\hline \multicolumn{3}{|c|}{$\begin{array}{l}\text { Adverse events, laboratory parameters and vital signs were analysed through descriptive statistics. } \\
\text { Ave }\end{array}$} \\
\hline \multicolumn{3}{|c|}{ Pharmacokinetic analysis } \\
\hline \multicolumn{3}{|c|}{$\begin{array}{l}\text { Descriptive statitistics on strontium concentrations were calculated at each nominal sampling time per group. } \\
\text { Strontium concentrations collected in the present study were pooled all together to build a population PK } \\
\text { model in order to analyse these sparse PK data, to explain the sources of variability through a covariate } \\
\text { analysis and to derive seconday PK parameters, i.e. AUC } \text { A }_{24 \text { ss }} \text { and } \mathrm{C}_{\text {min ss }} \text {. The method used for this population } \\
\text { PK analysis is described in a separate data analysis plan. }\end{array}$} \\
\hline
\end{tabular}




\begin{tabular}{|c|c|c|c|c|c|}
\hline $\begin{array}{l}\text { Name of Company: } \\
\text { I.R.I.S. } \\
50 \text { rue Carnot } \\
92284 \text { - Suresnes Cedex - FRANCE }\end{array}$ & \multicolumn{2}{|c|}{$\begin{array}{l}\text { Individual Study Table } \\
\text { Referring to Part } \\
\text { of the Dossier }\end{array}$} & \multicolumn{3}{|c|}{ (For National Authority Use only) } \\
\hline $\begin{array}{l}\text { Name of Finished Product: } \\
\text { Protelos } ® \text { Osseor } ® \text { (Europe) } \\
\end{array}$ & \multicolumn{2}{|l|}{ Volume: } & & & \\
\hline $\begin{array}{l}\text { Name of Active Ingredient: } \\
\text { Strontium ranelate (S 12911) } \\
\end{array}$ & \multicolumn{2}{|l|}{ Page: } & & & \\
\hline \multicolumn{6}{|c|}{$\begin{array}{l}\text { SUMMARY - CONCLUSIONS } \\
\text { STUDY POPULATION AND OUTCOME }\end{array}$} \\
\hline \multicolumn{6}{|c|}{ Disposition of patients } \\
\hline \multirow{2}{*}{ Status } & SrRan 1g & \multicolumn{2}{|c|}{ SrRan $2 g$} & Placebo & All \\
\hline & n (\%) & \multicolumn{2}{|c|}{ n (\%) } & n (\%) & n (\%) \\
\hline Included & $558(100.0)$ & \multicolumn{2}{|c|}{$566(100.0)$} & $559(100.0)$ & $1683(100.0)$ \\
\hline in compliance with the protocol & $520(93.2)$ & \multicolumn{2}{|c|}{$516(91.2)$} & $514(91.9)$ & $1550(92.1)$ \\
\hline with a protocol deviation at inclusion & $38(6.8)$ & \multicolumn{2}{|c|}{$50(8.8)$} & $45(8.1)$ & $133(7.9)$ \\
\hline Lost to follow-up & $1(0.2)$ & \multicolumn{2}{|c|}{$2(0.4)$} & $3(0.5)$ & $6(0.4)$ \\
\hline Withdrawn from the study due to & 245 (43.9) & \multicolumn{2}{|c|}{$238(42.0)$} & $220(39.4)$ & 703 (41.8) \\
\hline adverse event & $75(13.4)$ & \multicolumn{2}{|c|}{$84(14.8)$} & $58(10.4)$ & $217(12.9)$ \\
\hline lack of efficacy & $10(1.8)$ & \multicolumn{2}{|c|}{$9(1.6)$} & $9(1.6)$ & $28(1.7)$ \\
\hline non-medical reason & $151(27.1)$ & \multicolumn{2}{|c|}{$135(23.9)$} & $147(26.3)$ & $433(25.7)$ \\
\hline protocol deviation & $9(1.6)$ & \multicolumn{2}{|c|}{$10(1.8)$} & $6(1.1)$ & $25(1.5)$ \\
\hline Completed & 312 (55.9) & \multicolumn{2}{|c|}{$326(57.6)$} & $336(60.1)$ & 974 (57.9) \\
\hline in compliance with the protocol & $261(46.8)$ & \multicolumn{2}{|c|}{$274(48.4)$} & $284(50.8)$ & $819(48.7)$ \\
\hline with a protocol deviation after inclusion & $51(9.1)$ & \multicolumn{2}{|c|}{$52(9.2)$} & $52(9.3)$ & $155(9.2)$ \\
\hline under study treatment & $286\left(91.7^{*}\right)$ & \multicolumn{2}{|c|}{$301(92.3 *)$} & $312\left(92.9^{*}\right)$ & $899\left(92.3^{*}\right)$ \\
\hline \multicolumn{6}{|l|}{ Analysis Set } \\
\hline Full Analysis Set (FAS) & 445 (79.7) & \multicolumn{2}{|c|}{$454(80.2)$} & $472(84.4)$ & $1371(81.5)$ \\
\hline Per Protocol Set (PPS) & $277(49.6)$ & \multicolumn{2}{|c|}{$290(51.2)$} & $298(53.3)$ & $865(51.4)$ \\
\hline Safety Set (SS) & $548(98.2)$ & \multicolumn{2}{|c|}{$564(99.6)$} & $556(99.5)$ & $1668(99.1)$ \\
\hline
\end{tabular}

$n$ Number of patients by group in a given analysis set.

$\%$ calculated as percentage of randomised patients, except * \% of completed patients.

A total of 1683 patients were included and randomly assigned to one of the 3 treatment groups, with a well balanced distribution: 558 patients in the SrRan $1 \mathrm{~g}$ group, 566 in the SrRan $2 \mathrm{~g}$ group and 559 in the placebo group. Of them, 703 patients $(41.8 \%)$ withdrew from the study, mainly due to non-medical reasons (433 patients, $25.7 \%$ ). Among these 433 patients, 45 patients, $10.4 \%$ of the withdrawn patients withdrew due to: no patient's improvement (35 patients, $8.1 \%$ ), worsening of OA (9 patients, $2.1 \%$ ) or planned knee replacement (1 patient, $0.2 \%$ ) (complementary analysis).

Other reasons were: adverse events (217 patients, 12.9\%), with a slightly higher rate in the active treatment groups (13.4\% in the SrRan $1 \mathrm{~g}$ group, $14.8 \%$ in the SrRan $2 \mathrm{~g}$ group) than in the placebo group (10.4\%), lack of efficacy (28 patients, 1.7\%), and protocol deviations (25 patients, $1.5 \%)$. Six patients were lost-to-follow-up: 1 patient in the SrRan $1 \mathrm{~g}$ group, 2 patients in the SrRan $2 \mathrm{~g}$ group and 3 patients in the placebo group.

Overall, 784 patients $(46.6 \%$ of the randomised patients) prematurely discontinued the study treatment, mainly due to non-medical reasons $(25.1 \%)$ and adverse events $(18.1 \%)$.

Finally, 974 patients $(57.9 \%$ of the Randomised patients) completed the study of whom 899 patients $(92.3 \%$ of the completed patients) completed the study under treatment while the other $75(7.7 \%)$ had prematurely discontinued the study treatment.

Demographic and other baseline characteristics in the Randomised Set fulfilled the inclusion criteria of the study protocol, with no relevant between-group differences.

Patients were on average $62.9 \pm 7.5$ years old (range: $49-88$ years) and $40.6 \%$ were 65 years or older, with higher rate in the SR $2 \mathrm{~g}$ group than in the other groups: $38.2 \%$ in the SR $1 \mathrm{~g}$ group, $44.7 \%$ in the SR $2 \mathrm{~g}$ group, and $38.8 \%$ in the placebo group. The majority of patients were women $(70.4 \%)$. Mean BMI was $29.9 \pm 5.0 \mathrm{~kg} / \mathrm{m}^{2}$ and $44.2 \%$ of the patients were obese (BMI $\geq 30 \mathrm{~kg} / \mathrm{m}^{2}$ ). About half of them $(46.5 \%)$ reported alcohol consumption habit and $10.9 \%$ were smokers. 


\begin{tabular}{|c|c|c|c|c|c|c|}
\hline $\begin{array}{l}\text { Name of Company: } \\
\text { I.R.I.S. } \\
50 \text { rue Carnot } \\
92284 \text { - Suresnes Cedex - FRANCE }\end{array}$ & \multicolumn{3}{|c|}{$\begin{array}{l}\text { Individual Study Table } \\
\text { Referring to Part } \\
\text { of the Dossier }\end{array}$} & \multicolumn{3}{|c|}{ (For National Authority Use only) } \\
\hline $\begin{array}{l}\text { Name of Finished Product: } \\
\text { Protelos } ® \text { Osseor } ® \text { (Europe) } \\
\end{array}$ & \multicolumn{3}{|l|}{ Volume: } & & & \\
\hline $\begin{array}{l}\text { Name of Active Ingredient: } \\
\text { Strontium ranelate (S 12911) }\end{array}$ & \multicolumn{3}{|l|}{ Page: } & & & \\
\hline \multicolumn{7}{|c|}{$\begin{array}{l}\text { SUMMARY - CONCLUSIONS (Cont'd) } \\
\text { STUDY POPULATION AND OUTCOME (Cont'd) }\end{array}$} \\
\hline \multirow{2}{*}{\multicolumn{7}{|c|}{$\begin{array}{l}\text { Patients were suffering from knee OA for } 6.4 \text { years in average (median }=4.4 \text { years). Mean baseline } \\
\text { the target knee was } 3.50 \pm 0.84 \mathrm{~mm} \text { with a Kellgren and Lawrence rated stage II for a majority of } \\
(61.7 \%) \text { and stage III for } 38.1 \% \text { of them. The mean baseline WOMAC global score }(/ 300 \mathrm{n} \\
132.4 \pm 62.4 \mathrm{~mm} \text { with no between-group difference. } \\
\text { Main baseline demographic characteristics and characteristics of knee osteoarthritis } \\
\text { in the Randomised Set }(\mathbf{N}=\mathbf{1 6 8 3})\end{array}$}} \\
\hline & & & & & & \\
\hline & & $\begin{array}{l}\text { SrRan 1g } \\
(N=558)\end{array}$ & & $\begin{array}{l}5 \mathrm{~g} \\
566) \\
\end{array}$ & $\begin{array}{c}\text { Placebo } \\
(\mathrm{N}=559)\end{array}$ & $\begin{array}{c}\text { ALL } \\
(N=1683)\end{array}$ \\
\hline Age (years) & Mean \pm SD & $62.4 \pm 7.4$ & & \pm 7.5 & $62.8 \pm 7.5$ & $62.9 \pm 7.5$ \\
\hline Men & $\mathrm{n}(\%)$ & $164(29.4)$ & & $9.5)$ & $167(29.9)$ & $498(29.6)$ \\
\hline Women & $\mathrm{n}(\%)$ & $394(70.6)$ & & $0.5)$ & $392(70.1)$ & $1185(70.4)$ \\
\hline BMI $\left(\mathrm{kg} / \mathrm{m}^{2}\right)$ & Mean \pm SD & $30.1 \pm 5.1$ & & \pm 4.8 & $29.8 \pm 5.1$ & $29.9 \pm 5.0$ \\
\hline Kellgren and Lawrence stage Stage II & $\mathrm{n}(\%)$ & $341(61.2)$ & & 61.3) & $350(62.6)$ & $1038(61.7)$ \\
\hline Kellgren and Lawrence stage Stage III & $\mathrm{n}(\%)$ & $214(38.4)$ & & 38.5) & $209(37.4)$ & $641(38.1)$ \\
\hline Knee JSW reading by PMO (mm) & Mean \pm SD & $3.45 \pm 0.87$ & 3.5 & \pm 0.8 & $3.51 \pm 0.83$ & $3.50 \pm 0.84$ \\
\hline WOMAC global score /300 mm & Mean \pm SD & $132.0 \pm 62.0$ & 136. & \pm 62.5 & $129.0 \pm 62.5$ & $132.4 \pm 62.4$ \\
\hline Pain subscore $/ 100 \mathrm{~mm}$ & Mean \pm SD & $42.7 \pm 21.3$ & 44.5 & 21.8 & $42.2 \pm 21.6$ & $43.2 \pm 21.6$ \\
\hline Stiffness subscore $/ 100 \mathrm{~mm}$ & Mean \pm SD & $46.8 \pm 24.9$ & 48.3 & 25.0 & $45.5 \pm 25.2$ & $46.9 \pm 25.0$ \\
\hline Physical function subscore/100 mm & Mean \pm SD & $42.5 \pm 21.9$ & 43.7 & 22.5 & $41.0 \pm 22.4$ & $42.4 \pm 22.3$ \\
\hline Knee VAS pain /100 mm & Mean \pm SD & $52.6 \pm 22.5$ & & 21.9 & $53.7 \pm 22.4$ & $54.0 \pm 22.3$ \\
\hline
\end{tabular}

\section{Baseline selection visit}

$n$ number of patients

$\%$ calculated as percentage of randomised patients

At inclusion, $72.5 \%$ of the patients evaluable for the Kellgren and Lawrence (KL) score, had a hand OA (i.e. had at least 2 finger joints scored at a KL grade 2 or more at baseline) and 30\% of the patients had a family history of hand OA; $10.6 \%$ of the patients suffered from hip OA (based on clinical assessment, no systematic radiography was performed).

More than one third of the patients $(37.9 \%)$ were receiving a previous treatment for OA at inclusion, with a slightly lower frequency in the SrRan $1 \mathrm{~g}$ group than in the other groups: $33.9 \%$ in the SrRan $1 \mathrm{~g}$ group, $40.3 \%$ in the SrRan $2 \mathrm{~g}$ group, and $39.5 \%$ in the placebo group. These treatments were mainly antiinflammatory and antirheumatic products $(29.8 \%)$, mostly glucosamine $(11.4 \%)$, and corticosteroids for systemic use $(7.0 \%)$.

Most patients (99.3\%) reported a medical history in addition to OA, mostly vascular disorders (55.9\%) including hypertension (45.5\%), and metabolism and nutrition disorders (48.1\%), including hypercholesterolaemia (21.9\%). Consistently with their medical history, main concomitant treatments taken by the patients at inclusion consisted of agents acting on the renin-angiotensin system ( $29.6 \%$ of the patients), and lipid modifying agents $(25.2 \%)$.

Patients in the three treatment groups had similar demographic and baseline characteristics.

In the FAS, demographic and other baseline characteristics were close to those of the Randomised Set.

The global compliance was good: $86.5 \%$ of the patients had a compliance within the [85-130\%[ range, and the mean global compliance was $93.3 \pm 9.3 \%$. In the FAS, the mean treatment duration was $29.8 \pm 10.5$ months, i.e. 2.5 years, with a median of 35.7 months (i.e. about 3.0 years). 


\begin{tabular}{|c|c|c|c|c|}
\hline $\begin{array}{l}\text { Name of Company: } \\
\text { I.R.I.S. } \\
50 \text { rue Carnot } \\
92284 \text { - Suresnes Cedex - FRANCE }\end{array}$ & \multicolumn{2}{|c|}{$\begin{array}{l}\text { Individual Study Table } \\
\text { Referring to Part } \\
\text { of the Dossier }\end{array}$} & \multicolumn{2}{|c|}{ (For National Authority Use only } \\
\hline $\begin{array}{l}\text { Name of Finished Product: } \\
\text { Protelos } ® \text { Osseor } ® \text { (Europe) }\end{array}$ & \multicolumn{2}{|c|}{ Volume: } & & \\
\hline $\begin{array}{l}\text { Name of Active Ingredient: } \\
\text { Strontium ranelate (S 12911) }\end{array}$ & \multicolumn{2}{|l|}{ Page: } & & \\
\hline \multicolumn{5}{|c|}{ SUMMARY - CONCLUSIONS (Cont'd) } \\
\hline \multirow{2}{*}{\multicolumn{5}{|c|}{ 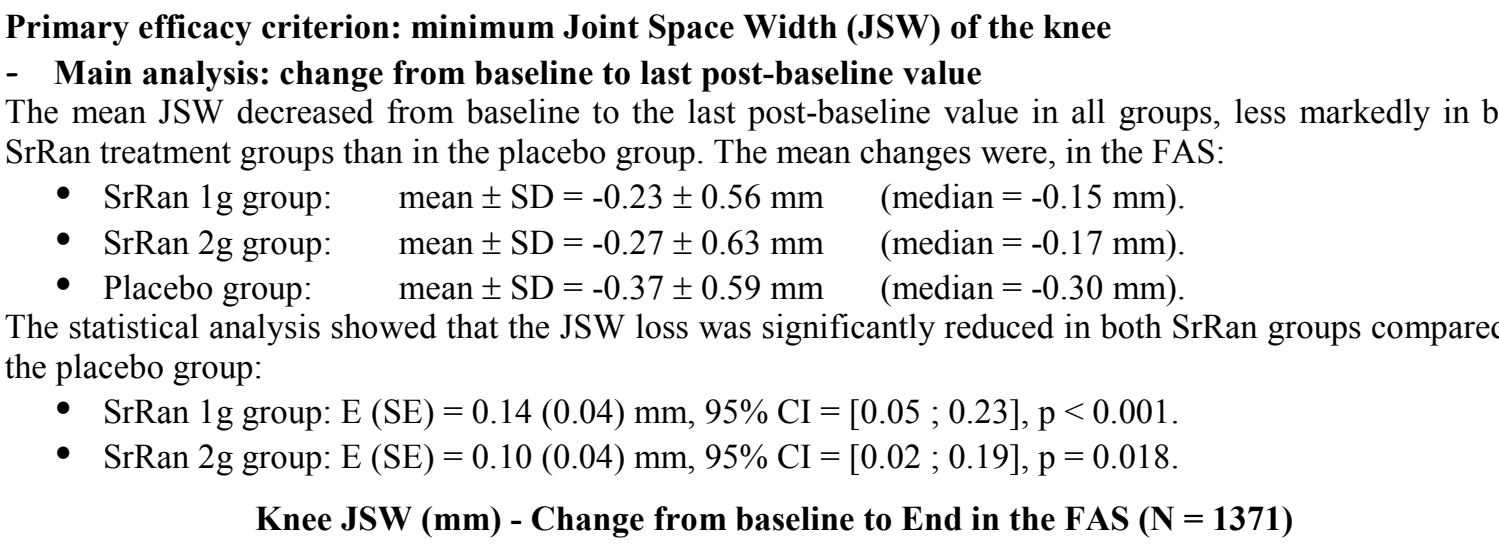 }} \\
\hline & & & & \\
\hline & & $\begin{array}{l}\text { SrRan 1g } \\
(\mathrm{N}=445)\end{array}$ & $\begin{array}{l}\text { SrRan 2g } \\
(\mathrm{N}=454)\end{array}$ & $\begin{array}{c}\text { Placebo } \\
(\mathrm{N}=472)\end{array}$ \\
\hline \multirow[t]{4}{*}{ Baseline } & $\mathrm{n}$ & 445 & 454 & 472 \\
\hline & Mean \pm SD & $3.45 \pm 0.86$ & $3.53 \pm 0.80$ & $3.51 \pm 0.82$ \\
\hline & Median & 3.48 & 3.51 & 3.48 \\
\hline & Min ; Max & $0.68 ; 6.00$ & $1.88 ; 6.58$ & $0.65 ; 5.80$ \\
\hline \multirow[t]{4}{*}{ END (last post-baseline value) } & $\mathrm{n}$ & 445 & 454 & 472 \\
\hline & Mean \pm SD & $3.23 \pm 1.06$ & $3.25 \pm 1.03$ & $3.15 \pm 1.00$ \\
\hline & Median & 3.27 & 3.22 & 3.13 \\
\hline & Min ; Max & $0.613 ; 5.91$ & $0.55 ; 6.48$ & $0.38 ; 5.54$ \\
\hline \multirow[t]{4}{*}{ Change from baseline to END } & $\mathrm{n}$ & 445 & 454 & 472 \\
\hline & Mean \pm SD & $-0.23 \pm 0.56$ & $-0.27 \pm 0.63$ & $-0.37 \pm 0.59$ \\
\hline & Median & -0.15 & -0.17 & -0.30 \\
\hline & Min ; Max & $-2.89 ; 1.67$ & $-4.27 ; 1.6$ & $-3.34 ; 1.59$ \\
\hline \multirow[t]{3}{*}{ Statistical analysis } & $\mathrm{E}(\mathrm{SE})^{(1)}$ & $0.14(0.04)$ & $0.10(0.04)$ & - \\
\hline & $95 \% \mathrm{CI}^{(2)}$ & {$[0.05 ; 0.23]$} & {$[0.02 ; 0.19]$} & - \\
\hline & p-value ${ }^{(3)}$ & & & - \\
\hline
\end{tabular}

$n$ number of assessable patients

(1) Estimate (Standard error) of the difference between treatment group means SrRan $1 \mathrm{~g}$ or $2 \mathrm{~g}$ minus placebo adjusted on baseline, gender, and centre; (2) Dunnetts 95\% Confidence interval of the estimate; (3) Dunnetts adjusted p-value (general linear model with baseline as covariate and gender and centre as fixed factors)

There was no statistically significant difference between the two SrRan groups $(p=0.38$, complementary analysis).

Sensitivity analyses (mixed model for repeated measurements, multiple imputation, pattern mixture model and analyses on the Randomised Set after substitution of missing JSW loss values in SrRan and placebo groups by the mean levels in the placebo group) confirmed the results of the main analysis.

Results were also confirmed in the PPS with slightly higher estimates of the between-group differences (SrRan 1 or $2 \mathrm{~g}$ versus placebo) than in the FAS:

- SrRan 1g group: $\mathrm{E}(\mathrm{SE})=0.16(0.05) \mathrm{mm}, 95 \% \mathrm{CI}=[0.05 ; 0.27], \mathrm{p}=0.003$.

- SrRan 2g group: $\mathrm{E}(\mathrm{SE})=0.13(0.05) \mathrm{mm}, 95 \% \mathrm{CI}=[0.02 ; 0.24], \mathrm{p}=0.015$.

The JSW results from LIEGE reading (second independent central reader) confirmed those from PMO central reading. 


\begin{tabular}{|l|l|l|}
\hline $\begin{array}{l}\text { Name of Company: } \\
\text { I.R.I.S. } \\
\text { 50 rue Carnot } \\
\text { 92284 - Suresnes Cedex - FRANCE }\end{array}$ & $\begin{array}{l}\text { Individual Study Table } \\
\text { Referring to Part } \\
\text { of the Dossier }\end{array}$ & (For National Authority Use only) \\
\hline $\begin{array}{l}\text { Name of Finished Product: } \\
\text { Protelos } ® \text { Osseor } ® \text { (Europe) }\end{array}$ & Volume: & \\
\hline $\begin{array}{l}\text { Name of Active Ingredient: } \\
\text { Strontium ranelate (S 12911) }\end{array}$ & Page: & \\
\hline SUMY & & \\
\hline
\end{tabular}

SUMMARY - CONCLUSIONS (Cont'd)

EFFICACY RESULTS (Cont'd)

\section{- Secondary analysis}

Knee JSW: change and relative change from baseline to each visit

The decrease in the mean JSW was significantly lower in the SrRan treatment groups in comparison with the placebo group at all visits (M12, M24, M36).

JSW (mm) - Change from baseline to each visit in the FAS $(\mathbf{N}=1371)$

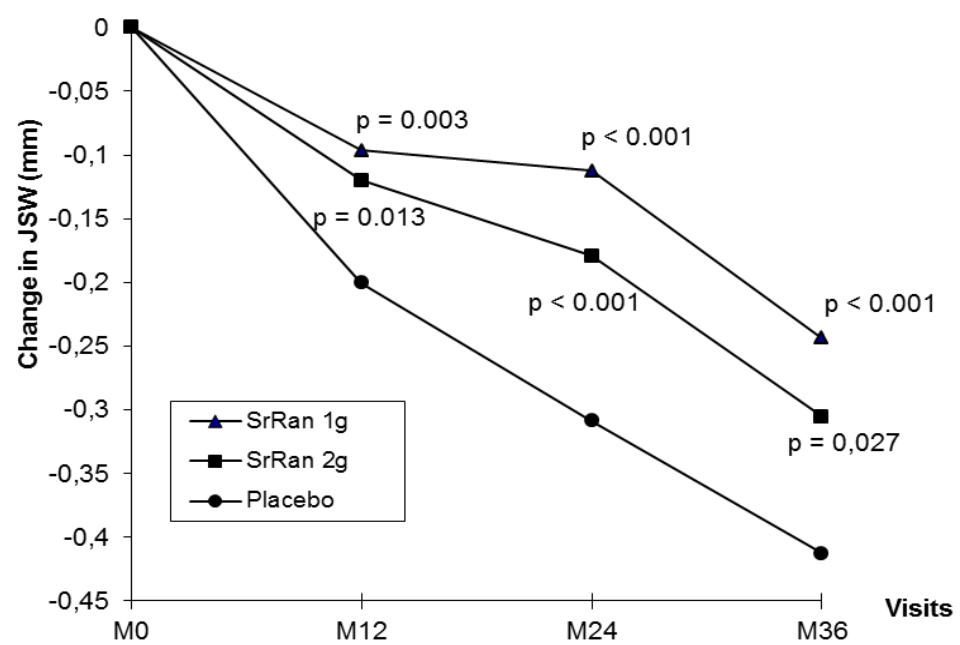

Statistical analysis SrRan groups versus placebo group Dunnetts adjusted p-value (general linear model with baseline as covariate and gender and centre as fixed factor)

The results expressed as relative changes confirmed those expressed as changes.

Subgroup analysis according to Kellgren-Lawrence stage at inclusion

Regardless of the baseline Kellgren-Lawrence stage, the JSW loss was lower in SrRan $1 \mathrm{~g}$ or $2 \mathrm{~g}$ treated patients compared to patients on placebo. The differences versus placebo were higher in patients with Kellgren-Lawrence stage II at inclusion i.e. the less severe patients:

- Kellgren-Lawrence stage II at inclusion (complementary analysis): JSW loss $=-0.18 \pm 0.54 \mathrm{~mm}$ in the SrRan $1 \mathrm{~g}$ group $(\mathrm{N}=268),-0.20 \pm 0.59 \mathrm{~mm}$ in the SrRan $2 \mathrm{~g}$ group $(\mathrm{N}=274)$, and $-0.33 \pm 0.57 \mathrm{~mm}$ in the placebo group $(\mathrm{N}=299)$.

Statistical analysis versus placebo:

- SrRan 1g group: $\mathrm{E}(\mathrm{SE})=0.16(0.05) \mathrm{mm}, 95 \% \mathrm{CI}=[0.05 ; 0.26], \mathrm{p}=0.003$.

- $\quad$ SrRan 2g group: $\mathrm{E}(\mathrm{SE})=0.14(0.05) \mathrm{mm}, 95 \% \mathrm{CI}=[0.03 ; 0.25], \mathrm{p}=0.007$.

- Kellgren-Lawrence stage III at inclusion: JSW loss $=-0.31 \pm 0.59 \mathrm{~mm}$ in the SrRan $1 \mathrm{~g}$ group $(\mathrm{N}=174)$, $-0.39 \pm 0.68 \mathrm{~mm}$ in the SrRan $2 \mathrm{~g}$ group $(\mathrm{N}=179)$, and $-0.44 \pm 0.63 \mathrm{~mm}$ in the placebo group $(\mathrm{N}=173)$. Statistical analysis versus placebo:

- $\quad$ SrRan 1g group: $\mathrm{E}(\mathrm{SE})=0.10(0.07) \mathrm{mm}, 95 \% \mathrm{CI}=[-0.05 ; 0.25], \mathrm{p}=0.241$.

- $\quad$ SrRan 2g group: $\mathrm{E}(\mathrm{SE})=0.04(0.07) \mathrm{mm}, 95 \% \mathrm{CI}=[-0.12 ; 0.18], \mathrm{p}=0.825$.

The lack of statistical significance could be explained by the limited number of patients in this subgroup. 


\begin{tabular}{|c|c|c|}
\hline & & \\
\hline & & \\
\hline & & \\
\hline \multicolumn{3}{|c|}{$\begin{array}{l}\text { SUMMARY - CONCLUSIONS (Cont'd) } \\
\text { EFFICACY RESULTS (Cont'd) } \\
\text { Secondary criteria } \\
-\quad \text { Radiological and radio-clinical progress } \\
\text { Radiological failures, defined as a knee JSW } \\
\text { less frequent in the SrRan treatment groups th } \\
-22.3 \% \text { in the SrRan } 1 \mathrm{~g} \text { group, } \mathrm{p}<0.00 \\
-25.6 \% \text { in the SrRan } 2 \mathrm{~g} \text { group, } \mathrm{p}=0.01 \\
-33.1 \% \text { in the placebo group. } \\
\text { The relative risk reduction (RRR) compared } \\
\text { patients needed to be treated to prevent one c } \\
\text { a NNT of } 14 \text { patients over the study period (c) }\end{array}$} \\
\hline \multicolumn{3}{|c|}{$\begin{array}{l}\text { The radio-clinical failures (defined as a knee JSW loss } \geq 0.5 \mathrm{~mm} \text { associated to a clinical change } \leq 20 \% \text { on } \\
\text { the pain subscale of the WOMAC score at the last post-baseline visit) were significantly less frequent in } \\
\text { the SrRan treatment groups than in the placebo group: } \\
\text { - } 7.7 \% \text { in the SrRan } 1 \mathrm{~g} \text { group, } \mathrm{p}=0.049 \text { versus placebo. } \\
\text { - } 6.5 \% \text { in the SrRan } 2 \mathrm{~g} \text { group, } \mathrm{p}=0.008 \text { versus placebo. } \\
\text { - } 11.6 \% \text { in the placebo group. } \\
\text { The RRR was } 34.0 \% \text { in the SrRan } 1 \mathrm{~g} \text { group with a NNT of } 26 \text { patients, and } 44.1 \% \text { in the SrRan } 2 \mathrm{~g} \text { group with } \\
\text { a NNT of } 20 \text { patients over the study period (complementary analysis). }\end{array}$} \\
\hline \multirow{2}{*}{\multicolumn{3}{|c|}{$\begin{array}{l}\text { The mean WOMAC global score decreased in all treatment groups during the study indicating } \\
\text { an improvement of the patients. The evolution of the change in WOMAC global score from baseline to each } \\
\text { post-baseline visit is illustrated in the figure below. } \\
\text { The improvement was more marked in the SrRan } 2 \mathrm{~g} \text { group than in the placebo group: the change from } \\
\text { baseline to the last post-baseline evaluation was in average more than } 10 \text { points higher in the SrRan } 2 \mathrm{~g} \text { group } \\
\text { than in the placebo group }(-51.9 \pm 66.1 \mathrm{~mm} \text { versus }-40.7 \pm 69.1 \mathrm{~mm} \text {, respectively). } \\
\text { The planned statistical approach considering all post-baseline values (mixed model for repeated measurements } \\
\text { with baseline as covariate and gender and centre as fixed factors) showed a statistical trend in favour of } \\
\text { the } 2 \mathrm{~g} \text { dose: }\end{array}$}} \\
\hline & & \\
\hline \multicolumn{3}{|c|}{$\begin{array}{l}\text { When using a similar statistical approach as for the primary criterion JSW, i.e. when considering the last post } \\
\text { baseline evaluation (Last Observation Carried Forward -LOCF- approach, complementary analysis), } \\
\text { the improvement was statistically significant in the SrRan 2g group while no statistically significant difference } \\
\text { was found between the SrRan 1g group and the placebo group: } \\
\text { - SrRan 1g group: E (SE) }=-1.3(4.0) \mathrm{mm}, \mathrm{p}=0.749 \text {. } \\
\text { - SrRan 2g group: E (SE) }=-8.0(4.0) \mathrm{mm}, \mathrm{p}=0.045 \text {. }\end{array}$} \\
\hline
\end{tabular}




\begin{tabular}{|l|l|l|}
\hline $\begin{array}{l}\text { Name of Company: } \\
\text { I.R.I.S. }\end{array}$ & $\begin{array}{l}\text { Individual Study Table } \\
\text { Referring to Part } \\
\text { of rue Carnot } \\
\text { 92284 - Suresnes Cedex - FRANCE }\end{array}$ & (For National Authority Use only) \\
\hline $\begin{array}{l}\text { Name of Finished Product: } \\
\text { Protelos } ® \text { Osseor }{ }^{\circledR} \text { (Europe) }\end{array}$ & Volume: & \\
\hline $\begin{array}{l}\text { Name of Active Ingredient: } \\
\text { Strontium ranelate (S 12911) }\end{array}$ & Page: & \\
\hline $\begin{array}{l}\text { SUMMARY - CONCLUSIONS (Cont'd) } \\
\text { EFFICACY RESULTS (Cont'd) }\end{array}$ &
\end{tabular}

WOMAC global score $(\mathrm{mm})$ - Mean changes from baseline to each visit in the FAS $(\mathrm{N}=1371)$

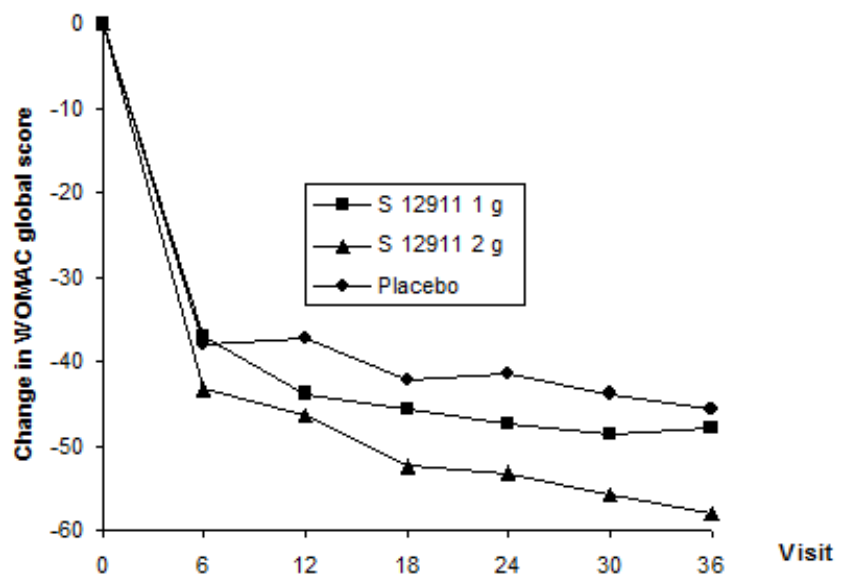

\section{- WOMAC subscores}

The treatment with SrRan $2 \mathrm{~g}$ resulted in an improvement in all three subscores, compared to placebo or SrRan $1 \mathrm{~g}$ treatments. The improvement in mean pain subscore was statistically significant in the SrRan $2 \mathrm{~g}$ group compared to placebo (change from baseline to last value: $-19.1 \pm 23.7 \mathrm{~mm}$ in the SrRan $2 \mathrm{~g}$ versus $-14.7 \pm 23.5 \mathrm{~mm}$ in the placebo group; $\mathrm{p}=0.028$, complementary analysis).

The rate of patients having an improvement of $20 \%$ in the average pain WOMAC subscore at last post-baseline evaluation (complementary analysis) was significantly increased in SrRan $2 \mathrm{~g}$ treated patients $(72.0 \%, \mathrm{p}=0.010$ versus $\mathrm{placebo})$ while this rate was similar in the SrRan $1 \mathrm{~g}$ group and in the placebo group (64.5\% and $64.0 \%$, respectively).

The rate of responders 50 was also higher in the SrRan $2 \mathrm{~g}$ group than in the placebo group $(50.7 \%$ versus $44.8 \%$, respectively), with a borderline significant $p$ value $(0.078)$. No statistically significant effect of SrRan $2 \mathrm{~g}$ was found in the rate of responders 70 .

\section{- VAS for the knee pain scale}

The VAS knee pain markedly decreased over time in all treatment groups, including in placebo-treated patients, indicating an improvement of the patients. At M36, the improvement was slightly more marked in the SrRan $2 \mathrm{~g}$ group $(-31.9 \pm 27.3 \mathrm{~mm})$ than in the SrRan $1 \mathrm{~g}$ group and the placebo group $(-26.0 \pm 27.8 \mathrm{~mm}$ and $-28.0 \pm 28.5 \mathrm{~mm}$, respectively) in the FAS, but there was no statistically significant difference between SrRan groups and placebo group.

\section{- Knee physical assessment}

Few patients were affected by symptoms of swelling (16.6\% of the patients), warmth $(3.4 \%)$ or effusion $(12.0 \%)$ at their entry in the study.

This rate remained roughly stable over the study, with no relevant differences between the SrRan treatment groups $(1$ or $2 \mathrm{~g})$ and the placebo group.

\section{- Indication to knee surgery}

The indication for a knee surgery during the study (defined as a knee prosthesis implanted or a withdrawal for planned knee replacement) was reported in 8 patients: 3 in the SrRan 1g group, 3 in the SrRan $2 \mathrm{~g}$ group and 2 in the placebo group. 


\begin{tabular}{|c|c|c|}
\hline $\begin{array}{l}\text { Name of Company: } \\
\text { I.R.I.S. } \\
\text { 50 rue Carnot } \\
92284 \text { - Suresnes Cedex - FRANCE }\end{array}$ & $\begin{array}{l}\text { Individual Study Table } \\
\text { Referring to Part } \\
\text { of the Dossier }\end{array}$ & (For National Authority Use only) \\
\hline $\begin{array}{l}\text { Name of Finished Product: } \\
\text { Protelos } ® \text { Osseor } ® \text { (Europe) }\end{array}$ & Volume: & \\
\hline $\begin{array}{l}\text { Name of Active Ingredient: } \\
\text { Strontium ranelate (S 12911) }\end{array}$ & Page: & \\
\hline \multicolumn{3}{|c|}{$\begin{array}{l}\text { SUMMARY - CONCLUSIONS (Cont'd) } \\
\text { EFFICACY RESULTS (Cont'd) } \\
\text { - E-diary: pain and medications for pain } \\
\text { Over the M0-M } 36 \text { period, a tendency to a lower frequency of patients receiving at least one pain medication } \\
\text { for the selected knee was observed in the SrRan } 2 \mathrm{~g} \text { group compared to the placebo group: } 88.8 \% \text { in the SrRan } \\
1 \mathrm{~g} \text { group, } 86.0 \% \text { in the SrRan } 2 \mathrm{~g} \text { group, versus } 90.4 \% \text { in the placebo group. The other information collected } \\
\text { by the patients in the e-diary, relative to pain (intensity, duration, number of days with pain) and } \\
\text { the consumption of pain medication (number of drugs, pharmacological class) were similar in all treatment } \\
\text { groups over the M0-M36 period. }\end{array}$} \\
\hline
\end{tabular}

\section{- Quality of life questionnaire (SF36)}

In all treatment groups, Physical Component Summary (PCS) and Mental Component Summary (MCS) scores remained stable or slightly increased from baseline to End. When analysing independently each dimension, between-group differences in the relative changes from baseline to End were of small amplitude, but generally in favour of the SrRan groups $1 \mathrm{~g}$ or/and $2 \mathrm{~g}$. In particular, the item "physical role" increased by $16.4 \pm 57.8 \%$ in the SrRan $1 \mathrm{~g}$ group, $25.3 \pm 107.1 \%$ in the SrRan $2 \mathrm{~g}$ group and $15.6 \pm 76.7 \%$, in the placebo group and "general health": $10.3 \pm 56.1 \%, 11.8 \pm 69.7 \%$ and $7.5 \pm 40.4 \%$, respectively.

\section{- Biochemical cartilage and bone markers}

Cartilage and synovitis markers

The levels of urinary CTX II (marker of cartilage degradation) decreased at M3 in the SrRan groups $(-0.045 \pm 0.220 \mu \mathrm{g} / \mathrm{mmol}$ creatinine in the SrRan $1 \mathrm{~g}$ group, $-0.064 \pm 0.297 \mu \mathrm{g} / \mathrm{mmol}$ in the SrRan $2 \mathrm{~g}$ group, $-0.001 \pm 0.238 \mu \mathrm{g} / \mathrm{mmol}$ in the placebo group) and remained lower than the baseline value at the following visits, whereas the levels were more fluctuating around baseline in the placebo group. The differences versus placebo were significant in both SrRan groups at M3 $(p=0.018$ in the SrRan 1g group and $p<0.001$ in the SrRan 2g group) and at M24 ( $p=0.007$ and $p=0.036$, respectively), suggesting a lower level of cartilage degradation in SrRan-treated patients than in placebo-treated patients.

No significant effect of SrRan treatment was detected in exploratory cartilage markers serum hyaluronic acid (marker of synovial inflammation) and serum CPII (marker of cartilage synthesis).

Bone markers

Compared to placebo, mean serum b-ALP increased in both SrRan treatment groups compared to placebo. The difference versus placebo was significant in both SrRan groups at M3, and at all the subsequent visits except M24 in the SrRan 2g group. Serum CTX I decreased in both SrRan treatment groups compared to placebo. The differences versus placebo were significant in both SrRan groups all the visits until M24. Mean changes from baseline to M36 were for bALP $(\mathrm{ng} / \mathrm{mL})$ : $0.06 \pm 4.01$ in the SrRan $1 \mathrm{~g}$ group, $0.58 \pm 4.37$ in the SrRan $2 \mathrm{~g}$ group, and $-0.19 \pm 4.20$ in the placebo group, and for CTX I $(\mathrm{ng} / \mathrm{mL}): 0.01 \pm 0.19$, $0.01 \pm 0.21$, and $0.02 \pm 0.22$, respectively. These results are in agreement with the dual mechanism of action of SrRan, as they suggest an increase in bone formation and a decrease in bone resorption with SrRan.

\section{- Knee MRI parameters}

The increase from baseline to the last post-baseline value in the global score for bone marrow lesion was slightly lower in the two treated groups (relative changes: $6.8 \pm 91.8 \%$ in the SrRan $1 \mathrm{~g}$ group, $19.0 \pm 110.6 \%$ in the SrRan $2 \mathrm{~g}$ group) than in the placebo group (35.4 $\pm 114.4 \%)$, although the between-group difference was not statistically significant. A slightly higher number of patients had an improvement (complementary analysis) in bone marrow lesion in both treated groups compared to placebo: 20 patients (17.9\%), 18 patients $(17.1 \%)$ and 14 patients $(12.7 \%)$ in the SrRan $1 \mathrm{~g}, 2 \mathrm{~g}$ and placebo group respectively. In parallel, the number of patients with a worsening was numerically lower in the SR $2 \mathrm{~g}$ group: 27 patients $(25.7 \%)$ in the SrRan $2 \mathrm{~g}$ group compared to 33 patients $(29.5 \%)$ and 31 patients $(28.2 \%)$ in the SrRan $1 \mathrm{~g}$ group and placebo group respectively. When considering each compartment (medial and lateral) separately, the absolute change in the medial bone marrow lesion score between the baseline and last post-baseline values was significantly lower in the SrRan $2 \mathrm{~g}$ group compared to the placebo group ( $p=0.034$, complementary analysis).

No clinically relevant change over time, nor between-group differences were detected regarding other MRI parameters. 


\begin{tabular}{|l|l|l|}
\hline $\begin{array}{l}\text { Name of Company: } \\
\text { I.R.I.S. } \\
\text { 50 rue Carnot } \\
\text { 92284 - Suresnes Cedex - FRANCE }\end{array}$ & $\begin{array}{l}\text { Individual Study Table } \\
\text { Referring to Part } \\
\text { of the Dossier }\end{array}$ & (For National Authority Use only) \\
\hline $\begin{array}{l}\text { Name of Finished Product: } \\
\text { Protelos@ Osseor }{ }^{\circledR} \text { (Europe) }\end{array}$ & Volume: & \\
\hline $\begin{array}{l}\text { Name of Active Ingredient: } \\
\text { Strontium ranelate (S 12911) }\end{array}$ & Page: & \\
\hline $\begin{array}{l}\text { SUMMARY - CONCLUSIONS (Cont'd) } \\
\text { EFFICACY RESULTS (Cont'd) }\end{array}$ &
\end{tabular}

A graphical exploratory data analysis investigating relationships between strontium serum exposure and cardilage degradation marker u-CTX II on one hand and u-CTX II and JSN on the other hand, revealed significant relationships between:

- Strontium $\mathrm{AUC}_{24, \mathrm{ss}}$ and u-CTX II expressed as percent change from baseline $(\mathrm{p}<0.01)$.

- U-CTX II (expressed as percent change from baseline) and JSN improvement $(\mathrm{p}<0.01)$.

Furthermore, a trend was found between the WOMAC score or the WOMAC pain subscore and either strontium exposure or SrRan dose. To consolidate PK/PD exporatory data analysis findings, population models were developed to describe on one hand, the relationship between strontium exposure and u-CTXII, and on the other hand, between strontium exposure and WOMAC score and WOMAC pain sub-score. Results showed a statistically significant relationship between the strontium exposure and the u-CTXII, confirming the structure-modifying effects of strontium ranelate. Regarding WOMAC score pain sub-score, the existence of statistically significant linear relationships between strontium exposure and WOMAC score and WOMAC pain sub-score in OA patients was demonstrated.

\section{SAFETY RESULTS}

Summary of safety results

\begin{tabular}{lcccc}
\hline & & $\begin{array}{c}\text { SrRan 1g } \\
(\mathbf{N}=\mathbf{5 4 8})\end{array}$ & $\begin{array}{c}\text { SrRan 2g } \\
(\mathbf{N}=\mathbf{5 6 4})\end{array}$ & $\begin{array}{c}\text { Placebo } \\
(\mathbf{N}=\mathbf{5 5 6})\end{array}$ \\
\hline Patients having reported & & & & \\
at least one emergent adverse event & $\mathrm{n}(\%)$ & $470(85.8)$ & $496(87.9)$ & $481(86.5)$ \\
at least one treatment-related emergent adverse event & $\mathrm{n}(\%)$ & $156(28.5)$ & $183(32.4)$ & $148(26.6)$ \\
at least one serious emergent adverse event (including death) & $\mathrm{n}(\%)$ & $93(17.0)$ & $93(16.5)$ & $97(17.4)$ \\
at least one treatment-related serious adverse event & $\mathrm{n}(\%)$ & $7(1.3)$ & $8(1.4)$ & $4(0.7)$ \\
an emergent adverse event leading to treatment stopped & $\mathrm{n}(\%)$ & $91(16.6)$ & $117(20.7)$ & $90(16.2)$ \\
at least one emergent VTE & $\mathrm{n}(\%)$ & $5(0.9)$ & $3(0.5)$ & $1(0.2)$ \\
Patients who died during the study* & $\mathrm{n}(\%)$ & $3(0.5)$ & $2(0.4)$ & $1(0.2)$ \\
\hline
\end{tabular}

$\%$ calculated as percentage of the patients of the safety Set except * calculated as percentage of patients in the Randomised Set VTE Venous thromboembolic event deep vein thrombosis and/ or pulmonary embolism

\section{Adverse events}

The overall frequency of patients who reported at least one emergent adverse event was close in the three treatment groups: 470 patients (85.8\% of the patients) in the SrRan $1 \mathrm{~g}$ group, 496 patients $(87.9 \%)$ in the SrRan $2 \mathrm{~g}$ group and 481 patients $(86.5 \%)$ in the placebo group.

The most frequently affected system organ classes were musculoskeletal and connective tissue disorders (44.2\% of the patients in the SrRan $1 \mathrm{~g}$ group and $46.8 \%$ in each of the other groups), infections and infestations (38.3\% in the SrRan 1g group, 37.4\% in the SrRan 2g group and 39.2\% in the placebo group) and gastrointestinal disorders $(29.7 \%, 29.1 \%$ and $29.9 \%$, respectively). Most system organ classes were reported at comparable incidence in the three groups, except for skin and subcutaneous tissue disorders more frequently reported in the SrRan $2 \mathrm{~g}$ group than in the placebo group group (16.3\% versus $12.2 \%$, respectively) and general disorders and administration site conditions ( $8.0 \%$ versus $5.2 \%$, respectively), and vascular disorders more frequently reported in the SrRan $1 \mathrm{~g}$ group than in the placebo group (17.9 versus $15.3 \%$, respectively).

The most commonly reported emergent adverse events were osteoarthritis $(16.4 \%$ in the SrRan $1 \mathrm{~g}$ group, $16.7 \%$ in the SrRan $2 \mathrm{~g}$ group and $17.3 \%$ in the placebo group) hypertension $(10.9 \%, 12.8 \%$ and $11.3 \%$, respectively) and arthralgia $(9.5 \%, 11.7 \%$, and $10.8 \%$, respectively). No relevant between-group differences were detected except an increased frequency in the SrRan $2 \mathrm{~g}$ group compared to placebo for diarrhoea: $7.8 \%$ versus $4.3 \%$, respectively, hypercholesterolemia: $7.3 \%$ versus $4.0 \%$, and pneumonia: $3.0 \%$ versus $1.1 \%$, respectively.

Emergent adverse events reported during the study with $\operatorname{SrRan} 2 \mathrm{~g}$ were in accordance with the expected known events. 


\begin{tabular}{|l|l|l|}
\hline $\begin{array}{l}\text { Name of Company: } \\
\text { I.R.I.S. } \\
\text { 50 rue Carnot } \\
\text { 92284 - Suresnes Cedex - FRANCE }\end{array}$ & $\begin{array}{l}\text { Individual Study Table } \\
\text { Referring to Part } \\
\text { of the Dossier }\end{array}$ & (For National Authority Use only) \\
\hline $\begin{array}{l}\text { Name of Finished Product: } \\
\text { Protelos® Osseor }{ }^{\circledR} \text { (Europe) }\end{array}$ & Volume: & \\
\hline $\begin{array}{l}\text { Name of Active Ingredient: } \\
\text { Strontium ranelate (S 12911) }\end{array}$ & Page: & \\
\hline $\begin{array}{l}\text { SUMMARY - CONCLUSIONS (Cont'd) } \\
\text { SAFETY RESULTS (Cont'd) }\end{array}$ &
\end{tabular}

Most emergent adverse events were graded as mild or moderate ( $94.6 \%$ of the events). Severe emergent adverse events occurred in 72 patients $(13.1 \%)$ in the SrRan $1 \mathrm{~g}$ group, 91 patients $(16.1 \%)$ in the SrRan $2 \mathrm{~g}$ group and 80 patients (14.4\%) in the placebo group. No relevant between-group differences were detected as regards the nature and the frequency of these severe events.

Most of the EAE recovered or were recovering/improving or recovered with sequelae ( $74.3 \%$ of the events in the SrRan $1 \mathrm{~g}$ group, $74.9 \%$ in the SrRan $2 \mathrm{~g}$ group and $74.5 \%$ in the placebo group). 5 EAEs led to death: 1 patient in the SrRan 1g group (histiocytosis haematophagic), 1 patient in the SrRan 2g group (sudden death) and 3 patients in the placebo group (general physical health deterioration, motor neuron disease, gastric cancer).

Treatment-related emergent adverse events were reported in 487 patients: 156 patients $(28.5 \%)$ in the SrRan 1g group, 183 patients (32.4\%) in the SrRan $2 \mathrm{~g}$ group and 148 patients (26.6 \%) in the placebo group. The system organ classes most commonly affected in the three groups were gastrointestinal disorders (13.0\% in the SrRan 1g group, $15.8 \%$ in the SrRan $2 \mathrm{~g}$ group and $12.4 \%$ in the placebo group) and skin and subcutaneous tissue disorders ( $4.4 \%, 6.2 \%$ and $4.9 \%$, respectively).

The frequency of patients who reported at least one emergent adverse event leading to treatment discontinuation was higher in the SrRan $2 \mathrm{~g}$ group than in the other groups: $20.7 \%$ versus $16.6 \%$ in the SrRan $1 \mathrm{~g}$ group and $16.2 \%$ in the placebo group. This higher percentage in the SrRan $2 \mathrm{~g}$ group was mainly attributable to skin and subcutaneous tissue disorders (2.4\% in the SrRan 1g group, $5.1 \%$ in the SrRan $2 \mathrm{~g}$ group and $2.5 \%$ in the placebo group). Among skin disorders, rash pruritic (reported in $0.5 \%, 1.1 \%$ and $0.7 \%$ of the patients, respectively) and allergic dermatitis (reported in $0.4 \%, 0.7 \%$ and $0.4 \%$ of the patients, respectively) were the most frequently associated with premature treatment discontinuation. The other most commonly affected system organ classes were gastrointestinal disorders $(6.2 \%, 4.8 \%$ and $5.6 \%$, respectively), mainly diarrhoea $(1.1 \%, 1.6 \%$, and $1.4 \%$, respectively) and musculoskeletal and connective tissue disorder $(1.5 \%, 3.4 \%$ and $2.0 \%$, respectively), mostly osteoarthritis $(0.4 \%, 0.9 \%$, and $0.5 \%$, respectively).

Emergent serious adverse events were reported in 283 patients with a similar frequency in the 3 treatment groups: 93 patients (17.0\%) in the SrRan 1g group, 93 patients (16.5\%) in the SrRan 2g group and 97 patients $(17.4 \%)$ in the placebo group. The most frequently affected system organ classes were musculoskeletal and connective tissue disorders $(3.3 \%, 5.0 \%$ and $4.1 \%$, respectively), including mostly osteoarthritis $(2.2 \%, 3.2 \%$ and $3.1 \%$, respectively), neoplasm benign, malignant and unspecified (incl. cysts and polyps) $(2.9 \%, 2.5 \%$ and $2.7 \%$, respectively) and cardiac disorders $(1.6 \%, 2.7 \%$ and $1.1 \%$, respectively). A total of 21 serious emergent adverse events were considered as treatment-related by the investigator: 8 events in each of the SrRan groups and 5 events in the placebo group.

During the treatment period, 11 VTE: 6 cases of deep vein thrombosis (DVT) and 5 cases of pulmonary embolism (PE) were reported in 9 patients:

- 5 patients in the SrRan 1g group: 3 patients had one DVT, one patient had one PE, and one patient had both one DVT and one PE.

- 3 patients in the SrRan 2g group: 2 patients had one PE and one patient had one DVT.

- 1 patient in the placebo group reported both one DVT and one PE.

The VTEs were considered as treatment-related according to the investigator except for one patient in the SrRan $1 \mathrm{~g}$ group for which the event followed a post-operative immobilisation, and one patient in the SrRan $2 \mathrm{~g}$ group, following air travel.

Moreover, after the study treatment period, one pulmonary thrombosis occurred 134 days after the last study drug intake in the SrRan $2 \mathrm{~g}$ group, considered as treatment-related according to the investigator. 


\begin{tabular}{|l|l|l|}
\hline $\begin{array}{l}\text { Name of Company: } \\
\text { I.R.I.S. }\end{array}$ & $\begin{array}{l}\text { Individual Study Table } \\
\text { Ro rue Carnot } \\
\text { 92284 - Suresnes Cedex - FRANCE } \\
\text { of the Dossier }\end{array}$ & (For National Authority Use only) \\
\hline $\begin{array}{l}\text { Name of Finished Product: } \\
\text { Protelos } ® \text { Osseor } ® \text { (Europe) }\end{array}$ & Volume: & \\
\hline $\begin{array}{l}\text { Name of Active Ingredient: } \\
\text { Strontium ranelate (S 12911) }\end{array}$ & Page: & \\
\hline $\begin{array}{l}\text { SUMMARY - CONCLUSIONS (Cont'd) } \\
\text { SAFETY RESULTS (Cont'd) }\end{array}$ &
\end{tabular}

Overall, 10 patients died ( 3 in each SrRan group, and 4 in the placebo group), all considered as not-treatment related.

6 deaths were rerorted during the study: 3 in the SrRan $1 \mathrm{~g}$ group, 2 in the SrRan $2 \mathrm{~g}$ group, and 1 in the placebo group.

- Two of these deaths occurred during the treatment period: histiocytosis haematophagic in the SrRan $1 \mathrm{~g}$ group and general physical health deterioration in the placebo group.

- Four deaths occurred after the treatment period: cerebral haemorrhage and myocardial infarction in the SrRan 1g group (3 months and 28 months after the last study drug intake, respectively), multi-organ failure and sudden death in a patient having a pre-existing metastatic lung cancer in the SrRan $2 \mathrm{~g}$ group (about 2 months and 67 days after the last study drug intake, respectively).

Moreover, 4 patients died after the study period: 1 patient in the SrRan $2 \mathrm{~g}$ group (4 months after the last study drug intake) and 3 patients in the placebo group, all considered as not treatment-related.

\section{Laboratory safety tests}

Neither clinically relevant changes over time nor differences between the three groups were detected. Some between-group differences were observed for CPK, calcium and phosphorus. Mean CPK levels increased from baseline to end in both SrRan groups (mean $\pm \mathrm{SD}=11.7 \pm 85.6 \mathrm{IU} / \mathrm{L}$ in the SrRan $1 \mathrm{~g}$ group and $20.7 \pm 104.4 \mathrm{IU} / \mathrm{L}$ in the SrRan $2 \mathrm{~g}$ group) whereas it remained stable in the placebo group (mean $\pm \mathrm{SD}=-0.4 \pm 68.1 \mathrm{IU} / \mathrm{L})$. High emergent out-of-reference-range values for CPK were more frequently reported in the SrRan groups than in the placebo group: $17.6 \%$ in the SrRan $1 \mathrm{~g}$ group, $19.4 \%$ in the $\mathrm{SrRan} 2 \mathrm{~g}$ group versus $10.6 \%$ in the placebo group. Most of these patients had abnormal CPK values in the ]1x $-2 \mathrm{x}$ ] upper limit of the normal (ULN) range $(93.3 \%$ of patients in the SrRan $1 \mathrm{~g}$ group, $85.0 \%$ in the SR $2 \mathrm{~g}$ group, and $87.3 \%$ in the placebo group). CPK values were in the $] 2-3]$ X ULN range for $1.1 \%, 10 \%$, and $5.5 \%$ of the patients, respectively. CPK values between 3 and 5 ULN affected few patients in any group, and values above 5 ULN were detected in 3.3\% (3 patients), 1.0\% (1 patient), and 7.3\% (4 patients), respectively, of the patients having abnormal values.

In both SrRan groups, slight changes were observed in phosphocalcic homeostasis parameter: decrease in blood calcium and increase in blood phosphorus.

Emergent (PCSA) were sparse $(<5 \%$ in any group) except for the following parameters for which high PCSA values were more frequently reported in the SrRan treatment groups than in the placebo group:

- C-reactive protein: $20.2 \%$ in the SrRan $1 \mathrm{~g}, 22.5 \%$ in the SrRan $2 \mathrm{~g}$ versus $16.0 \%$ in the placebo group, respectively.

- Phosphorus: $8.6 \%, 20.0 \%$ versus $3.1 \%$, respectively.

Neither clinically relevant changes nor differences between the three groups were detected for mean changes in haematological or hemostasis parameters, except for factor VIII, for which the mean $( \pm$ SD) increase from baseline to end was higher in both SrRan groups compared to placebo group: $14.1 \pm 38.4 \%$ in the SrRan $1 \mathrm{~g}$, $21.8 \pm 43 \%$ in the SrRan $2 \mathrm{~g}$ versus $10.1 \pm 41.4 \%$ in the placebo group). Emergent PCSA were sparse except for the following parameters for which high PCSA values were more frequently reported in the SrRan groups than in the placebo group:

- Prothrombin fragment 1+2: 14.4\% in the SrRan 1g group, 15.8\% in the SrRan $2 \mathrm{~g}$ group, and $12.2 \%$ in the placebo group.

- Factor VIII: $4.8 \%, 8.5 \%$, and $3.0 \%$, respectively.

- Fibrinogen: $3.9 \%, 4.9 \%$ versus $1.3 \%$, respectively.

Vital signs

Neither clinically relevant changes over time nor differences between groups were detected for vital signs. 


\begin{tabular}{|c|c|c|}
\hline $\begin{array}{l}\text { Name of Company: } \\
\text { I.R.I.S. } \\
\text { 50 rue Carnot } \\
92284 \text { - Suresnes Cedex - FRANCE }\end{array}$ & $\begin{array}{l}\text { Individual Study Table } \\
\text { Referring to Part } \\
\text { of the Dossier }\end{array}$ & (For National Authority Use only) \\
\hline $\begin{array}{l}\text { Name of Finished Product: } \\
\text { Protelos } ® \text { Osseor } ® \text { (Europe) }\end{array}$ & Volume: & \\
\hline $\begin{array}{l}\text { Name of Active Ingredient: } \\
\text { Strontium ranelate (S 12911) }\end{array}$ & Page: & \\
\hline \multicolumn{3}{|c|}{$\begin{array}{l}\text { This international double-blind controlled study, conducted in } 1683 \text { male or female patient } \\
\text { aged } \geq 50 \text { years with primary knee osteoarthritis, demonstrated the superiority of a } 3 \text {-year treatmen } \\
\text { with strontium ranelate } 1 \mathrm{~g} \text { and } 2 \mathrm{~g} \text { daily over placebo in reducing radiographic progression of knec } \\
\text { osteoarthritis. The mean loss in joint space width (primary efficacy criterion) was significantly reduced } \\
\text { in patients treated with } \mathrm{SrRan} 1 \mathrm{~g} \text { and } 2 \mathrm{~g} \text { as compared to those treated with placebo: the difference } \\
\text { versus placebo was of } 0.14 \mathrm{~mm}(\mathrm{p}<0.001) \text { in favour of SrRan } 1 \mathrm{~g} \text { and } 0.10 \mathrm{~mm}(\mathrm{p}=0.018) \text { in favour } 0 \\
\text { SrRan } 2 \mathrm{~g} \text {. The reduction in } \mathrm{JSW} \text { loss was not significantly different between the two doses of SrRar } \\
\text { tested (1g and } 2 \mathrm{~g}) \text {. }\end{array}$} \\
\hline \multicolumn{3}{|c|}{$\begin{array}{l}\text { The analysis of individual joint space narrowing showed that significantly fewer patients in the SrRan } \\
\text { groups than in the placebo group had radiographic failure }(\mathrm{JSN} \geq 0.5 \mathrm{~mm}): 22.3 \% \text { of the patients in } \\
\text { the SrRan } 1 \mathrm{~g} \text { group }(\mathrm{p}<0.001), 25.6 \% \text { in the SrRan } 2 \mathrm{~g} \text { group }(\mathrm{p}=\mathbf{0 . 0 1 2}) \text { versus } 33.1 \% \text { in the placebo } \\
\text { group. Radiological and radioclinical progression of the OA was lower in the SrRan groups than in } \\
\text { the placebo group, with a statistically significant between-group difference. }\end{array}$} \\
\hline \multicolumn{3}{|c|}{$\begin{array}{l}\text { This finding supports the clinical benefit of the treatment with SrRan, since the reduced loss of JSW has } \\
\text { been shown to be predictive of better OA outcomes including a decreased risk of undergoing } \\
\text { osteoarthritis related joint surgery during the ensuing } 5 \text { years. }\end{array}$} \\
\hline \multicolumn{3}{|c|}{$\begin{array}{l}\text { The structure-modifying effects observed with both doses of SrRan were associated, for the SrRan } \\
2 \mathrm{~g} \text { dose, with improvements in symptoms of osteoarthritis as evaluated by the WOMAC global score } \\
\text { and pain subscore for the target knee. A general trend in favour of SrRan } 2 \mathrm{~g} \text { was also found for } \\
\text { algo-functional assessments of the hand (AUSCAN) and the hip (VAS pain scale). }\end{array}$} \\
\hline \multicolumn{3}{|c|}{$\begin{array}{l}\text { The overall incidence of emergent adverse events and of serious emergent adverse events was similar in } \\
\text { the three treatment groups. The safety profile of SrRan } 2 \text { g/day in patients with OA was similar with } \\
\text { that previously described in osteoporotic patients. Venous thromboembolic events were infrequent, bu } \\
\text { were more frequent with strontium ranelate than with placebo. Clinical laboratory evaluation yielded } \\
\text { expected results: slight changes in CPK and phosphocalcic homeostasis parameters, and revealed no } \\
\text { new or unexpected biological concerns. }\end{array}$} \\
\hline
\end{tabular}

